\title{
CONSTRUCTING A RELIGIOUS WORLDVIEW: WHY RELIGIOUS ANTIREALISM IS STILL INTERESTING
}

\section{THOMAS SCHÄRTL}

\author{
University of Augsburg
}

\begin{abstract}
After a short overview of anti-realist positions within the philosophy of religion, the following paper argues in favour of a moderate version of religious anti-realism. Especially the notions of 'revelation' and 'religious experience' seem to suggest that certain dichotomies (i.e. the fact/values dichotomy) that are typical for realism cannot be upheld consistently within philosophy of religion. However, the end of the paper shows a different route, which might overcome the realism/antirealism dichotomy as such.
\end{abstract}

\section{WHAT ARE WE TALKING ABOUT?}

A very prominent definition of theistic/theological antirealism turns out to be somewhat inadequate. Michael Scott and Andrew Moore, for instance, have introduced the following prima-facie insightful distinction:

Theological realism is the theory that there is a transcendent divine reality, the principal object of religious belief and language, the existence of which is not contingent upon (or, positively, is independent of) our thoughts, actions and attitudes. Theological non-realists maintain that meaningful religious faith and language are possible without there being any such independently existing entity. ${ }^{1}$

Scott's and Moore's definition of 'theological non-realism' is, taken at face value, not a description of theological or religious anti-realism, but

\footnotetext{
${ }^{1}$ Michael Scott and Andrew Moore, 'Can Theological Realism Be Refuted?', Religious Studies, 33 (1997), 401-418, esp. 402.
} 
rather an explication of atheism, cloaked in a version of non-realism. It is pretty obvious that only a certain fraction of contemporary philosophy of religion wants to be associated with that sort of non-realism, which is pretty much the same thing as what we should call 'irrealism' (a point of view we will deal with in a couple of paragraphs). It is not wrong to offer this sort of narrow definition of non-realism. Unfortunately, however, this definition leads to a rather unwelcome consequence: It blurs the lines of the differences in anti-realistic concepts within philosophy of religion, since too many philosophical approaches that are fond of anti-realism are pushed towards irrealism and, at the end of the day, are predominantly interpreted as 'irrealist'. But this is neither fair nor correct. Only a few authors - literature on that topic usually mentions Don Cupitt, but we need to be careful with that assessment ${ }^{2}-$ fulfil the description as an approach that turns anti-realism into irrealism.

Certain confusions in labelling might tell us that we are in need of a sharper distinction of different types of antirealism especially in the area of theology and philosophy of religion. Therefore, it would be beneficial to introduce Crispin Wright's term ${ }^{3}$ 'irrealism' and Simon Blackburn's phrase 4 'quasi-realism' to our vocabulary; but we have to use those terms with a grain of salt when it comes to philosophy of religion. Thus the following definitions are rather stipulative than explicative or descriptive by referring back to the leading philosophers that might have coined the phrase in question.

Friendly irrealism should be seen as a position that holds certain ontological commitments under certain circumstances to be empty; we could think of philosophers like Ludwig Feuerbach, who don't believe in the existence of God, but still think that religious language is meaningful if, for example, re-interpreted from a certain perspective, since religious God-talk is the result of a misleading reference shift that ascribes idealized properties to an individual entity called God while the properties in question must actually be ascribed to an abstract entity

${ }^{2}$ Cf. Don Cupitt, Taking Leave of God (London: SCM Press, 1980). For further discussions compare Peter Byrne, God and Realism (Aldershot: Ashgate, 2003), pp. 107125, esp. 109-118.

${ }^{3}$ Cf. Crispin Wright, 'Realism, Anti-Realism, Irrealism, Quasi-Realism', in Saving the Differences: Essays on Themes from Truth and Objectivity (Cambridge: Harvard University Press, 2003), pp. 11-47.

${ }^{4}$ Cf. Simon Blackburn, Essays in Quasi-Realism (Oxford - New York: Oxford Univerity Press, 1993). 
called mankind. ${ }^{5}$ Contemporarily, Pirmin Stekeler-Weithofer's approach could be seen as a version of friendly irrealism with regard to religion. ${ }^{6}$ Although Stekeler-Weithofer doesn't actually believe in the existence of God, he is able to treat religious language as a system of symbols keeping an honourable and very dignified image of human nature, which has the fascinating capacity to transcend its very own boundaries, alive. ${ }^{7}$ Another, equally sophisticated form of friendly irrealism can be found in Markus Gabriel's remarks on religion. To him the phrase 'God' is more or less a symbol or a placeholder for the infinity of social relations we may (theoretically) encounter as finite human beings. ${ }^{8}$ But there is no additional meaning to the phrase 'God' - at least not in the ways classical theism may have pictured it.

Hostile irrealism, on the other hand, would agree that the ontological commitments of religious sentences are empty, but would add that we have no justification to treat religious utterances as something meaningful. Sigmund Freud's position might come close to hostile irrealism, since he regards religious propositions as the fallout of psychological facilities that aren't always properly aimed at healthy or truthful goals. ${ }^{9}$

Quasi-realism, instead, should be defined as the position that ascribes rationality and, therefore, cognitive value to religious utterances, but would insist that religious sentences do not have truthmakers in a way statements about the physical world have; while statements about the physical world are 'made true' (and, of course, one needs to ask whether or not this is a meaningful phrase as it stands) by physical states of affairs, for religious quasi-realism there are no comparably well-identified 'religious' states of affairs (consisting of specifically religious entities or entities that instantiate specifically religious properties) that could work as the requested truthmakers.

${ }^{5}$ Cf. Ludwig Feuerbach, Das Wesen des Christentums (Stuttgart: Reclam, 1969 [RP 2011]), pp. 52-79.

${ }^{6}$ We may also wonder whether or not friendly irrealism is the only positive answer an empiricist philosophy can give to the question of religion. Cf. Andrew Moore, Realism and Christian Faith: God, Grammar, and Meaning (Cambridge: Cambridge University Press, 2003), pp. 41-43.

${ }^{7}$ Cf. Pirmin Stekeler-Weithofer, Sinn (Berlin - New York: De Gruyter, 2011) pp. 43-70, 121-144.

${ }^{8}$ Cf. Markus Gabriel, Warum es die Welt nicht gibt (Berlin: Ullstein, 2013), pp. 177-213, esp. 208-213.

${ }^{9}$ Cf. Sigmund Freud, Die Zukunft einer Illusion (Leipzig: Internationaler psychoanalytischer Verlag, 1927). 
Thus, the first order of business should be to refrain from treating irrealism as a version of anti-realism. Irrealism is - plain and simple the denial of the existence of certain types or certain tokens of being. You can thus be an irrealist about unicorns but a realist with regard to superstrings at the lowest micro-level of the universe. You can be a realist concerning everyday objects but an irrealist when it comes to universals, etc. Positions like that do not even touch the true motivation of antirealism as we should try to understand it. Something similar should be said for quasi-realism. Its immediate concern is the relation between certain statements and their presumed truthmakers holding on to the idea that states of affairs are rather peculiar entities most intimately related to the nature of facts. ${ }^{10}$ Quasi-realism may be combined with anti-realism and the other way round; but they shouldn't be equated. In an unequivocal way, anti-realism needs to be anchored in the minddependency-thesis. For this is what makes anti-realism most interesting and most controversial. Some support for this proposal may be offered by the other side of the spectrum. Therefore, William Alston's explication of 'metaphysical realism' is quite noteworthy:

As a preliminary characterization of the kind of metaphysical realism being considered here, it is opposed to the view that whatever there is, is constituted, at least in part, by our cognitive relations thereto, by the ways we conceptualize it or construe it, by the language we use to talk about it or the conceptual scheme(s) we use to think of it. ${ }^{11}$

So, we have to raise the question: What is anti-realism in the philosophy of religion? To come up with a satisfying answer it might be helpful to turn to a more general characterization of anti-realism as such. Following Raimo Toumela, who offers a survey of the most basic antirealistic convictions, we can name seven different 'symptoms' that lead to an anti-realistic approach:

${ }^{10} \mathrm{I}$ am aware that this is a very charitable interpretation of quasi-realism. In literature we also find the idea that quasi-realism is always accompanied by fictionalism. And one may wonder whether or not fictionalism is disastrous to the self-understanding of religious expressions and their commitments. Cf. David Lewis, 'Quasi-Realism is Fictionalism', in Fictionalism in Metaphysics, ed. by Mark Kalderon (Oxford: Clarendon Press, 2005), pp. 314-321; a critical response to that comes from Simon Blackburn, 'Quasi-Realism No Fictionalism', in Fictionalism in Metaphysics, pp. 322-338.

${ }^{11}$ William P. Alston, 'What Metaphysical Realism is Not', in Realism and Antirealism, ed. by William P. Alston (Ithaca - London: Cornell University Press, 2002), pp. 97-115, esp. 97-98. 
(1) The analytic-synthetic as well as the scheme-content distinction in the traditional sense should be abolished (cf. Quine).

(2) The Myth of the Given should be rejected (cf. Sellars).

(3) It is central to make the distinction between naturalistic (nonepistemic) and epistemic discourse or, if you prefer, between the order of being and the epistemic order (cf. Sellars).

(4) The assumption of psychological nominalism is correct, viz., all awareness of abstract entities is at bottom a linguistic affair (cf. Sellars).

(5) Language and justification are social and historical affairs (this comes from pragmatism).

(6) There is no strict fact-value dichotomy to be made at least on the level of ordinary language (pragmatism, hermeneutics).

(7) The main goal of philosophy is edification and conversation (hermeneutics). ${ }^{12}$

Not all of these items on the list have to go into your cart if you want to buy in to anti-realism. Especially (7) represents a rather metaphilosophical conviction, as Tuomela points out, ${ }^{13}$ which is not required to be an antirealist although some prominent antirealists in the more general areas of theoretical philosophy (take, for instance, Richard Rorty) or in the rather special area of philosophy of religion (a paradigmatic case would be D. Z. Phillips) would sign off on (7). However, the heart of the anti-realistic creed is written down in sentences (2)-(6). But still, these theses report only symptoms of anti-realism (or descriptions of symptoms that are, indeed, extraordinarily helpful in identifying antirealism in the history of philosophy and in contemporary debates) but do not show the core of anti-realism which, to my estimation, must consist of a more or less elaborate rejection of a global or, at least, regional mindindependency-thesis. But still, the above-mentioned symptoms are very helpful in drawing the lines between anti-realism and irrealism since neither of those sentences implies subjectivism or non-cognitivism or the straightforward denial of the existence of God. That some friendly irrealists might take advantage of one or the other of these characteristics of anti-realism is a matter of fact but not a matter of necessary entailment.

${ }^{12}$ Raimo Tuomela, 'The Myth of the Given and Realism', Erkenntnis, 29 (1988), 181200, esp. 191.

${ }^{13}$ Ibid., pp. 191-192. 
Analogically, there is the possibility of combining anti-realism with quasi-realism when it comes to the notion of truth and the 'notorious' truthmaker question (as some would say); but only a few of the abovementioned criteria - especially (4) and (5) which, by themselves, are neither necessary nor sufficient conditions of anti-realism - connect directly to quasi-realism. A strong link between irrealism and quasirealism in religion can be established if we take a more or less empiricist interpretation of factualism as the ultimate starting point. ${ }^{14}$

Given that Tuomela's checklist dates back to the times when the realism/antirealism controversy originated, one might wonder whether or not this list is still accurate. So, for example, the realist might not want to have the 'myth of the given' strapped to his back (see item (2) on the list). And, equally, the antirealist might not want to be associated with versions of 'psychologism' - or whatever could be linked to that notion - and the like (compare item (2) of Tuomela's list). Given that there are more subtle versions of realism ${ }^{15}$ and antirealism available in the meantime, Tuomela's list needs improvement. With respect to more recent discussions of the topic, the following list might serve as a better litmus test of (metaphysical) antirealism. Therefore, let us suppose that it is typical for antirealism:

(1) to be opposed to the fact-/value-dichotomy as well as the content/ attitude- and the content/form-dichotomy,

(2) to treat reference as an affair that essentially reflects a speaker's attitudes and convictions (which implies to be critical about a causal theory of linguistic reference) and to treat justification as linguistic and, therefore, cultural affairs,

(3) to criticize a connection between truth and justification that is too loose (while emphasizing that truth is idealized justification),

(4) to reject a correspondence theory of truth in favour of coherence in order to treat 'truthmaking' as a predominantly linguistic and logical affair,

${ }^{14}$ For a deeper analysis of these connections compare Michael Scott, 'Wittgenstein and Realism', Faith and Philosophy, 17 (2000), 170-190, esp. 174-177.

${ }^{15}$ It is up for discussion whether any version of realism that does not hold equally strong antitheses to what Tuomela has pinned down as the antirealist's Creed might turn into 'blind' realism. See Robert Almeder, 'Blind Realism', Erkenntnis, 26 (1987), 57-101. Presumably, a blind realist might be opposed to items (2) to (4) on my new list of criteria, which shows that blind realism is a significantly weaker position than straightforward metaphysical realism. 
(5) to be deflationist with regard to the common truthmaker talk (since this is seen as the last outpost of the correspondence theory of truth),

(6) to point out that there is not just one language/conceptual system that can be justified as the solely correct description of the world,

(7) to be nominalist and/or pragmatist about abstract entities (like universals, rules, laws, etc.).

This list is still just an enumeration of certain symptoms that are quite typical for an antirealist position. But the core-conviction is not even on the list yet. It is the idea (as indirectly presented by Alston's definition of metaphysical realism) that the mind-independency-thesis is wrong.

\section{FLAVOURS OF RELIGIOUS ANTI-REALISM}

With some of the above developed distinctions in mind it becomes quite interesting to take a second look at the notorious role models of religious anti-realism, especially D. Z. Phillips, Gordon Kaufman and John Hick. There is the unanimous conviction within the realistic camp of philosophy of religion that Phillips's, Kaufman's and Hick's views contain the leitmotif of anti-realistic opposition to realism. But what does this mean specifically?

In Phillips we find the idea that there are no unequivocal standards of referring or justifying, so that religious language has to be treated differently compared, for example, to scientific language:

The whole conception [...] of religion standing in need of justification is confused. Of course, epistemologists will seek to clarify the meaning of religious statements, but as I have said, this means clarifying what is already there awaiting such clarification. Philosophy is neither for nor against religion: 'it leaves everything as it is'. This fact distinguishes philosophy from apologetics. It is not the task of the philosopher to decide whether there is a God or not, but to ask what it means to affirm or deny the existence of God. ${ }^{16}$

16 D. Z. Phillips, The Concept of Prayer (London: Routledge \& Kegan Paul, 1968), p. 10. I took the quote from this book on purpose since it belongs to the early stage reflections of Phillips's position. His later stage writings are, of course, more elaborate and more outspoken when it comes to the explication of his antirealistic position. The leitmotif, nevertheless, stays the same. 
Admittedly, certain aspects in Phillips's writings tend sometimes towards irrealism with regard to very specific commitments - take for instance the concept of prayer as the idea of asking or begging God for something - but it would be way too harsh to say that Phillips is an irrealist regarding the existence of God. In many of his writings he reflected on the question of what will follow for us once we agree that there is no unequivocal notion of existence so that God's existence cannot be asserted and justified on the same basis as sentences which affirm the existence of electrons, dinosaurs or genes. In the way Phillips approached the problem, religious antirealism starts with the most fundamental insight that 'to exist' and 'to be real' and other phrases of this kind are extremely sensitive with regard to the subject they are predicated from. Furthermore, none of those phrases are interchangeable. In order to find out what we mean by those phrases we have to take a look at the context of meaningful communication a context in which especially our actions in combination with our linguistic behaviour reveal the specific meaning of existence-claims. Within this framework an antirealist reconstruction of the ontological argument (as famously proposed by Rush Rhees) might be developed out of the idea that one doesn't understand the meaning and impact of the word 'God' as the 'Id Quo Maius Cogitari Nequit', if one pretends to have understood the meaning of 'God' as the IQMCN and simultaneously claims the non-existence of God. As a matter of fact, Phillips's position is not so much that of anti-realism, let alone irrealism, but rather an attack on naïve religious realism and an attack on philosophies that, in the name of an overall applicable realism, are willing to oppose theism on a, as they pretend to do, purely scientific basis.

Now let us turn to our second example: Gordon Kaufman. In his classic monograph God: The Problem, he introduces what we need to call religious quasi-realism since we find an apophatic overtone in his message. As a conclusion he presents the idea that the word 'God' is a symbol:

The word 'God' not only designates a transcendent reality never accessible to our observation or even our speculation; it also implies an ordering of the world in personalized and purposive terms. Though God himself may escape our every attempt to search him out, the world that we can and do experience can be apprehended as his. That is, we can perceive it and live in it as created by God and ordered to his purposes, though we may not be able to prove either that this is in fact true of the world or that God does himself exist. 
The matter may be compared to the convergence of a number of main highways toward a city lying some distance off the map. There is an order in the converging lines which can be clearly perceived, but the ground and center of that order (the point of intersection) is not open to view. We can, if we choose, orient ourselves and our travels by reference to the supposed city off the edge of the map, even though we have no further chart that actually shows that the city is there or just what are its contours and character. ${ }^{17}$

This analogy is as revealing as helpful since it tells us that Kaufman is in one way or the other bothered with factualism; and indeed factualism is what nourishes Kaufman's version of quasi-realism. We can give his main intuitions the following argumentative outline:

i. The reference of a proper name is not problematic if and only if the referent is a distinguishable object located in time and space.

ii. The referent of the word 'God' is not located in time and space.

iii. Thus, the reference of the proper name 'God' is problematic.

From iii. Kaufman derives the insight that it is necessary for us to treat the word 'God' not as a proper name at all (but as a symbol). The hidden agenda of anti-factualism becomes obvious once we replace key phrases like 'proper name' with 'sentence', 'referent' with 'truthmaker' and the 'location in space and time' with '(empirical) state of affairs'. It is now easy to see why Kaufman offers religious quasi-realism as a way out: He gives credit to the more or less positivist doctrine which assumes that some main constituents of states of affairs need to be entities that are embedded in space and time. Of course, Kaufman does not want to give up the rationality of religious language and the business of theology, which is connected to it. Therefore, a detour seems to be necessary: Given that our actions and our behaviour are seated in space and time, God-talk becomes relevant once it is reconstructed in a way that makes the connection between the symbol and our actions obvious. There are no physical states of affairs that are immediate truthmakers of sentences containing the word 'God' in an affirmative sense; but they are indirectly important insofar as they enter as facts into human actions and behaviour. Of course, the easiest philosophical answer to that would be to say that Kaufman's initial premise is wrong and that his notion of

17 Gordon D. Kaufman, God: The Problem (Cambridge: Harvard University Press, 1972), pp. 96-97. 
facts gives a restricted version of factualism too much credit. So - is that all there is to religious quasi-realism?

For Kaufman, quasi-realism has two main advantages: If it is combined with some straightforward concept of anti-realism, the claims of factualism can themselves be remodelled in anti-realistic terms, i.e. they belong to a certain worldview which rests on human conceptualizations and constructions. ${ }^{18}$ Furthermore, anti-realism may be the engine that keeps a critical hermeneutics of religious imagery going. If we regard a large number of traditional concepts of God as results of human means of conceptualization, we might feel entitled to critically review those images and even replace them. But such a replacement couldn't be successful, if the premise of every interpretation of religious language was irrealism. Only by believing in an ultimate reality does a reform of our concepts of God make sense:

If God is understood as the serendipitous creativity manifest throughout the cosmos - instead of as a cosmic person - and we humans are understood as deeply embedded in, and basically sustained by, this creative activity in and through the web of life on planet Earth, we will be strongly encouraged to develop attitudes and to participate in activities that fit properly into this web of living creativity [...]. ${ }^{19}$

It is open for discussion whether or not Kaufman's ultimate concept of God (which itself is the product of some sort of Ecoliberation Theology) might turn into irrealism or not. For our present goal it is enough to see that religious quasi-realism as the justification of critical hermeneutics will provoke almost naturally a theological opposition. But is this party that resides at the other side of the spectrum really opposed to quasirealism? ${ }^{20}$ Again, most of the time religious irrealism seems to be the danger many want to avoid right from the start in eradicating every form of anti-realism.

${ }^{18}$ Cf. Gordon D. Kaufman, God: The Problem, pp. 203-225.

${ }^{19}$ Gordon D. Kaufman, 'Mystery, God, and Constructivism', in Realism and Religion: Philosophical and Theological Perspectives, ed. by Andrew Moore and Michael Scott (Aldershot: Ashgate, 2007), pp. 11-29, esp. 27.

${ }^{20}$ Sometimes, indeed, it is irrealism which is under attack. And some other times it is what one usually calls 'constructivism' (usually including a rather odd notion of constructivism). An interesting example is Katherine Sonderegger, 'The Character of Christian Realism', Scottish Journal of Theology, 57 (2004), 451-465, who directly confronts realism and anti-realism based on the claim that an idea of a mind-dependent reality is untenable. Nevertheless, it is interesting to see that the author is not engaging in an argument here but simply claims that one must accept realism, cf. ibid., p. 452. 
Let us turn finally to our last example usually assessed as a version of religious/theological anti-realism. In John Hick's Interpreting Religion we find the idea that the ultimate reality is beyond the scope of our knowledge and understanding ${ }^{21}$ so that most, if not all, of the religious expressions we encounter turn out to be more or less adequate symbolizations meant to deal with an ultimate that cannot be approached. It is crystal clear that Hick's philosophy of religion sticks to metaphysical realism when it comes to the existence of the ultimate. ${ }^{22}$ But, what about the rest? A closer look will show that Hick's approach is a version of negative theology, since he strictly denies that religious expressions can be taken literally because of our lack of knowledge. The structure of his argument can be pinned down in the following way:

(1) Reliably assertive sentences, which are open to truth-evaluation, presuppose sufficient knowledge of the entity the sentences are meant to refer to.

(2) We do not have sufficient knowledge of God, since God as the ultimate reality is beyond any means of gaining knowledge.

(3) The required presuppositions of assertive religious language cannot be fulfilled.

We may question the connection between sufficient knowledge and reliable assertion right from the start, while saying that reasonable belief will do. Still, this argument does not support religious anti-realism directly although it may well be said that some sort of expressivism fits perfectly into this picture. But this is just a contrastive expressivism, which is not applicable to the very existence of the ultimate itself. Additionally, theological quasi-realism might fit this picture as well: If Hick's epistemology forces us to steer away from any form of causal theory of linguistic reference, religious language needs to be based on a different foundation. The Wittgensteinian idea of language as a rule-governed enterprise comes in sight and would render theology a hermeneutical science occupied with the unfolding and explication of the rules in question. ${ }^{23}$ But, obviously the resulting version of quasirealism coming from this merger between Hick and Wittgenstein is by no

\footnotetext{
${ }^{21}$ Cf. John Hick, An Interpretation of Religion (London: Macmillan, 1989).

${ }^{22}$ Cf. Roger Trigg, 'Realism and Antirealism', in A Companion to Philosophy of Religion, ed. by Philip L. Quinn and Charles Taliaferro (Oxford: Blackwell, 1999), pp. 213-220, esp. 218-219.

${ }^{23}$ Cf. Andrew Moore, Realism and Christian Faith, pp. 75-79.
} 
means fictionalistic because a fictionalist assessment would presuppose a view from above which, according to Hick and Wittgenstein, we don't have. Furthermore, rules of language have an objective status although it makes no sense to ask whether or not they can be ratified by certain truthmakers.

\section{A MIND-DEPENDENT REALITY}

After this brief overview over different versions and flavours of anti-realism we need to get our head around the quintessential minddependency thesis. Before we open the door for two strains of arguments, we need to take a closer look at some serious attacks on religious antirealism. These attacks did not originate from the realistic camp but come from philosophers that are, to a certain extent, sympathetic to antirealism (at least in specific areas). The first attack says that anti-realism is just too easy a way for religious commitments to weasel away from the ontological and epistemological burden of proof. In a scarcely cloaked cynical manner Simon Blackburn underlines that religion cannot keep up its demands and obligations if its language is reconstructed predominantly in an anti-realistic way as a system of symbolic language and performative rites. ${ }^{24}$

The second attack comes from philosophy of science indicating that religious and theological anti-realists have underestimated the returning strength of scientific realism and should, for their own good, deal with the question of whether or not theism has any explanatory power and whether or not it is necessary to treat God like a theoretical entity in natural sciences. This attack continues to say that any kind of scientific anti-realism that takes scientific progress as a litmus test for the performance of sciences must stick to the criterion of the explanatory power of an entity whose existence is uncertain but whose treatment 'as if it existed' is validated by its explanatory role. Otherwise this endorsement of anti-realism would fall prey to the problems the first attack indicated: it would be too easy a way out of the forces of theistic scepticism and atheism. Both attacks reflect a strategy well known in the philosophy of religion: They want religious assertions to be interpreted

${ }^{24}$ Cf. Simon Blackburn, 'Religion and Ontology', in Realism and Religion (see footnote 19), pp. 47-59, esp. 56-59. 
realistically in order to open them to evidentialist scrutiny and atheistic criticism. ${ }^{25}$

What can we say about those attacks? Andrew Moore votes for a big separation between the endeavour of science and the aims of religion and religious language. ${ }^{26}$ While the former is literally tied to the explanation of phenomena in the universe, the latter's business is to see the world in a specific light, which for Andrew Moore is the light of revelation. ${ }^{27}$ Therefore, religious systems cannot be compared to scientific theories and the crucial role of certain entities, whose existence seemed to be postulated by religious systems, is not that of theoretical entities living up to the standards of best explanations. ${ }^{28}$ Furthermore, Moore adds that religious or theological realism is under a lot of pressure itself, since once the explanatory role of religion is conceded - it unavoidably starts competing with scientific theories with respect to the explanation of certain phenomena (like religious experience and other things one could take as indications for the existence of God). ${ }^{29}$

In addition to what Moore has pointed out, we can add two more observations regarding the advantages of religious anti-realism: First of all, revelation is a concept that is, by all means, mind-dependent. In

${ }^{25}$ Cf. Alexander Bird, 'Scientific and Theological Realism', in Realism and Religion (see footnote 19), pp. 61-81, esp. 67-79.

${ }^{26}$ Although I am in favour of this separation there might still remain some interesting parallels that are useful in describing what we mean by religious anti-realism. Take, for instance, the problem of under-determined scientific theories and the case in which two equally solid theories are consistent with the phenomena but, after all, we cannot decide whether one or the other is true (or in any meaningful way privileged over the other). This case can be construed as an argument in favour of anti-realism. Cf. Lars Bergström, 'Underdetermination and Realism', Erkenntnis, 21 (1984), 349-365. The analogy could help us to see how different religious worldviews (although they do not have the status of theories, of course) are in accordance with the phenomena; but yet we may not be able to decide which one is true.

${ }^{27}$ Cf. Andrew Moore, Realism and Christian Faith, pp. 45-55.

${ }^{28} \mathrm{Cf}$. Andrew Moore, Realism and Christian Faith, p. 66: 'I suggest that when they speak of God's unobservability, theological realists make a category mistake by transferring the "grammar" of observation in the created realm to the creator. In the realm of created reality with which science deals, the "grammar" of observation implies practices such as prediction, experimental control, and - if we are realist - the ascription of truth to theories; by contrast, the "grammar" of theology involves believing and obedience. Thus I shall argue that though there is a sense in which it is proper to speak of God's revelation as his making himself observable, this is not a making visible in the same sense in which electron microscopes make, say, genes visible.'

${ }^{29}$ Ibid., p. 56. 
a universe without rational subjects and without consciousness there could be no revelation. Additionally, from a purely epistemological and hermeneutical angle, revelation is a way of interpretation: treating certain texts or events as a measure of the encounter with the divine while those texts or events do not offer any proof of their divine origin that is beyond reasonable doubt. The history of the critique of religion may teach us that there is not a single text in any religious tradition whose existence and content cannot alternatively be explained in purely naturalistic terms (even if those explanations should require some acrobatic skills from the critic); the same goes for certain events that are assessed as normative and revelatory by a certain religious tradition. What religious anti-realism adds to the equation is what we should call the irreplaceable premise of faith. In the light of faith, which at least partially has to be reconstructed in doxastic and epistemic terms, the concept of revelation makes sense. In the light of faith we treat certain texts of events as if they were revealed although we are in no position to leave behind the interpretational help this concept is offering us whenever we reflect on the content and extension of revelation. The reality of revelation is that very concept which serves as an irreplaceable tool to evaluate events or texts under the perspective of faith. To explain why this is tied to antirealism we can make use of what Hilary Putnam famously used as a starting point for his idea of internal realism: the distinction of primary and secondary qualities (as it goes back to Descartes and is found in a number of empiricist writers). Even if we might have to admit that there is no evidence for a complete disjunction of primary and secondary qualities parallel to the distinction between mind-independent and mind-dependent properties, we would still be left with the troubling question of whether or not there are religiously significant 'revelatory properties' that somehow supervene on physical properties in a law-like manner. The religious anti-realist would add that there won't be any such revelatory properties 'out there in the world' since revelation is a concept that is meant to help us interpret the world of facts in a certain way.

That this is a crucial point becomes clear once we take a look at Kathrin Sonderegger's version of what she called 'Christian realism'. She says something about the interpretation of Biblical texts and the notion of the universe being God's creation:

The opening verses of Genesis are an image - or better, an archetype - of the very nature of reality: that our cosmos exists in relation to God; that 
they belong together; that God is the willing origin of this cosmos; and the proper name for this relation is 'creation' and the proper character of our cosmos is 'creaturely'. Now, there may be recognizable signs of this creatureliness in the cosmos itself: the apostle Paul appeared to think so. But there may not. Proper theological realism does not rest upon the claim that reality as created must show forth its creatureliness apart from Christian faith: Christian realism is not 'mind or language independent' in that sense. Rather, the true character of our cosmos is revealed and depicted in the beginning of scripture; and the true character of the Almighty as creator is exemplified there. Proper Christian realism begins with these two themes. ${ }^{30}$

Of course, one can have a realistic notion of creation. Maybe this is the case if you try to find a rock-solid basis for the cosmological argument. But, of course there is also the possibility, even the need for an anti-realistic notion of creation. This one is in place whenever we add the premise of faith to our interpretation of facts - especially when the summation of facts results in a still underdetermined picture of the world. Sonderegger's interpretation of the cosmos as God's creation is precisely a version of an anti-realistic notion of creation. There is nothing wrong with that. But it sounds like muddying the waters if one calls that 'realism' - even the addendum 'Christian' won't make that more realistic in a meaningful sense of the word. What Sonderegger seems to aim at is the idea that beyond our symbols and concepts there is still the transcendent reality of God. So, at the end of the day she is concerned with irrealism. This becomes even more apparent when Sonderegger qualifies her version of 'Christian realism' in ways that eventually resemble the characteristics of anti-realism:

Christian realism is not, in fact, a method and position as constructivism is. Realism is not the starting point or axiom that construction is; nor is it an epistemic or metaphysical theory. Christian realism is not a theory at all. Rather, it is something deeper, more primal, formative and indispensable than any theory or method could be. We might call it a 'form of life' if Wittgenstein's term did not, ironically, signal irrealism to many commentators; and we might call it a 'picture' or 'characterization' should these terms, too, not appear to connote imagination or wish. We might call it consensus gentium (the consensus of the people), should

${ }^{30}$ Katherine Sonderegger, 'The Character of Christian Realism', p. 456. 
that term of protestant scholasticism not suggest to us a wish rather than an acknowledgement; or 'marks', as of the true church, should that term not be so enmeshed in confessional polemics. It may well be that Bishop Butler's aphorism - that every thing is what it is and not another thing applies to realism as well: we cannot state it fully or precisely in any other terms. So G. E. Moore viewed the 'good': it was both transcendent and primitive. The real is surely that, if anything deserves that claim. So Christian realism is 'common-sense', 'rule of thumb', ordinary or 'close at hand'. It is pre-theoretical - if that did not sound so theory-laden - or the 'given' - if that were not even more theorybound from Kant forward. Christian realism is the reception of the world, the real world. Nothing less question-begging than that can be said. ${ }^{31}$

Maybe what Sonderegger seeks to emphasize is that the Christian worldview is basic in the sense that we do not have to sit down and develop a theory about the world wondering whether and how we can privilege this theory over and above a rivalling one. Maybe she thinks that a certain worldview - like the Christian one - emerges out of natural inclinations and not out of voluntary and deliberate consensus. Still, this doesn't count against the mind-dependency thesis which is couched in the 'premise of faith' that elucidates a certain religious worldview.

The second addition (which might help us to see the advantages of religious anti-realism) stems from Mark McLeod. It basically says that anti-realism can tolerate and bear contradictions without the goal to overcome these contradictions at the earliest convenience. ${ }^{32}$ Thus, a religious-antirealist might be willing to name the difference between a theistic and a naturalistic worldview, but she could live with a situation in which none of these competing systems or languages can be evidentially proven to be the only legitimate 'description' of the world. Given that there are certain convictions that turn into the concepts that we use to explain or interpret the facts around us, the differences between a naturalistic and a theistic worldview may turn out to be beyond dissolution in case the concepts in question have a pre-rational origin. In short: Anti-realism is a way to deal with contradictions in presenting what we could call a Goodman-world (or, to use another phrase, a holistic worldview) in which each of the claims is well established and in keeping these worlds

${ }^{31}$ Ibid., pp. 452-453.

${ }^{32}$ Cf. Mark McLeod, 'Realism and Irrealism: A Dialogue', in Realism and Antirealism (see footnote 11), pp. 26-40, esp. 30. 
separate by showing that an overarching Goodman-world or worldview is out of sight.

In a methodologically more transparent way, McLeod's hints were foreshadowed by Immanuel Kant. In his Kritik der reinen Vernunft he keeps the most noble thoughts of special metaphysics as 'regulative ideas' of pure reason ${ }^{33}$ - ideas reason is desperately in need of for its own sake. It is because of the underlying concept of a higher unity that these regulative ideas are so needed: The unity of the self in order to have an enduring and stable bearer of all thoughts and concepts, ${ }^{34}$ the unity of the world in order to have the order and the framework for the objects of experience to be given, and above all the unity of mind and world - given in the notion of God - in order to have a higher synthesis which eventually correlates mind and world. On the other hand, Kant tries to show that we literally run into dead ends once we try to find evidence for what is indicated in these ideas on the basis of facts that are presented by experience. Based on facts we cannot decide whether there is a stable and enduring subject of experience. Based on facts we cannot decide whether or not there is a whole world ordered and given to us that allows us to experience it and act freely in it. ${ }^{35}$ And based on facts alone we cannot say whether or not there is a higher government and the ultimate cause of the world we call God. ${ }^{36}$ Additionally, we run into the problems of contradiction. If we follow Kant, the notions of freedom and the idea of the causal closure of the world are incompatible but yet equally needed to understand the moral order on the one hand and the order of events in the world on the other. There is a contradiction here, which cannot be eliminated based on the rivalling concepts that are in place. So, the only way is to embrace anti-realism. But, especially the example of freedom shows that, for Kant, the concept we embrace as if it were real is not a fiction (in any inferior sense) but something objective that gets its normative status because we cannot avoid conceiving of us as free if we want to have a consistent understanding of the depth and moral dignity of our actions. ${ }^{37}$ Thus, from a certain perspective we must conceive of ourselves as being free and responsible agents. But from another perspective (especially when we need to take a look at the world

\footnotetext{
${ }^{33}$ Cf. Immanuel Kant, Kritik der reinen Vernunft, AA 330-335.

${ }^{34}$ Cf. Immanuel Kant, Kritik der reinen Vernunft, AA 262-270.

${ }^{35}$ Cf. Immanuel Kant, Kritik der reinen Vernunft, AA 309-314.

${ }^{36}$ Cf. Immanuel Kant, Kritik der reinen Vernunft, AA 315-321.

${ }^{37}$ Cf. Immanuel Kant, Kritik der reinen Vernunft, AA 366-368.
} 
from a naturalistic point of view), we must treat mundane events as if they were parts of an entirely closed causal chain. Anti-realism is the only way out if we cannot set aside one concept from the other.

We can expand Kant's anti-realism even to concepts that are needed in theology; ${ }^{38}$ take for instance the problem of divine foreknowledge and human freedom. Imitating Kant's style we could say that both concepts are an unavoidable and integral part of a religious worldview: The idea of divine foreknowledge keeps God's supreme sovereignty intact theologically and offers also a pillar stone of spirituality. If everything is foreknown by God, nothing is alien to him and everything there will be is already in his hands. Nevertheless, this idea puts a heavy burden on the concept of the openness of the future, which seems to be a prerequisite for (morally meaningful) human freedom. Thus, we cannot take away the idea of future events being not yet actual and us having a major influence on the course of the world that lies ahead of us. If contradiction is unavoidable and resolvable only at the cost of abandoning one or the other concept, antirealism offers a helping hand: We are in a position to say that the contradictions that seem to fall upon us theologically (and even spiritually) are merely conceptual and that we are entitled to stick to both concepts or ideas as if they were true if we can show that these concepts are needed for the sanity of reason, the coherence of our actions, the integrity of our most fundamental convictions that contain the rulebook of our discursive commitments and so on.

Don Cupitt alludes to this very Kantian problem of the contradictions that might arise from irreplaceable but yet incompatible concepts of God:

[T] raditional theism makes three claims, as follows:

(i) God is active;

(ii) God is immutable; and

(iii) God is in this life known only through his effects.

How can these three claims be reconciled? It would seem that if an account of God must be such that these three things can all be said of him, then something like our own account has to be given.

For on our account God is not really a person or a substance but [...] an unconditionally demanding and inflexible principle which as we choose it and lay it upon ourselves generates certain effects within us; theistic faith, the drama of the spiritual life and so on. ${ }^{39}$

${ }^{38}$ For a Kantian lead, cf. Immanuel Kant, Kritik der reinen Vernunft, AA 457-461.

${ }^{39}$ Don Cupitt, Taking Leave of God, p. $102 \mathrm{f}$. 
Cupitt's conclusion sounds admittedly like fictionalism. And we have to discuss the question of whether interpretation as some sort of construction entails fictionalism. However, we can start with Cupitt's diagnosis of realistic theism and come up with a more Kantian solution: If for the sanity of reason and for the coherence of our moral and spiritual actions we need to think of God being active as well as of God being immutable, etc., and if those concepts turn out to be incompatible (especially when we take them at face value), we need to treat them as regulative ideas that reveal their indispensability by the means in which they orient our lives.

Regulative ideas are of course mind-dependent because they crucially emerge from the activities of reason, especially from the inner dynamics of the cognitive powers of reason and its aim to find order and consistency. Regulative ideas depend upon what we think cannot be thought otherwise; from here they gain their objectivity. Nevertheless, the world as sum of facts remains quite ambiguous once we try to identify the truthmakers of these ideas out there in the world. We establish the regulative ideas - including the idea of God - as if they were true ${ }^{40}$ still being aware that there won't be any truthmakers available apart from our thinking. The ambiguity of the facts won't go away - especially not once we raise the big questions about freedom, the substantiality of the self, the order of the world, the ultimate aim of the world, and God. But based on how reason itself performs we embrace those concepts as ideas that in the end govern how we interpret the facts and how we approach the world. From a Kantian perspective we can embed the premise of faith into the premises of ultimate concepts that emerge out of reason's dynamics towards the ultimate - having nothing but reason itself as their truthmaker.

\section{RELIGIOUS EXPERIENCES AND THEIR INTERPRETATION}

But maybe the above-mentioned mixture of Kant with Cupitt is too much for the contemporary taste in philosophy of religion. The realistic opponent may still deny that a Kantian analysis which is combined with the notion of ambiguity of what we perceive to be factual is correct and convincing. Still, the opponent might want to see a convincing argument that helps her to see why anti-realism is the best we can get. Maybe one

${ }^{40}$ Cf. Immanuel Kant, Kritik der reinen Vernunft, AA 412-413. 
argument can help us out here, which could be called the argument from religious experience. The result might not be global anti-realism but, at least, a regional form of anti-realism which is still strong enough to be taken seriously.

Of course, it is too global a question whether an adequate notion of experience as such leads to anti-realism. Even if we want to avoid the two horns of the dilemma which a prima-facie reconstruction of experience might have in store for us, namely the myth of the given ${ }^{41}$ on the one hand and detached coherentism on the other, a McDowellian solution to the problem, which consists in affirming that experience is as rational as it is conceptual, starting with the conceptual aspects of our openness for experience and their possible impact on the rational status of our convictions, ${ }^{42}$ won't do for religious experience. There are too many loose ends in that very specific story since a huge variety of phenomena can serve as the experiential input to which an articulation of religious experiences is the result and since there is, strictly speaking, no specific input that could ever necessitate the articulation of religious experiences. ${ }^{43}$ Of course, there have been attempts to show that certain inputs will trigger certain religious propositions - take for instance Alvin Plantinga's Warranted Christian Belief; however such concepts are far from having established convincingly that a Conformity Principle of Perception (CPP), which holds that certain specific inputs will trigger certain propositions in every possible world that is inhabited by rational beings similar to us, is applicable to religious experiences. Since Plantinga sticks to (CPP) in one way or the other, the multitude of religious symbols and expressions, to his view, has to be traced back to severe malfunctions of certain

${ }^{41}$ For the discussion of an intimate connection between the myth of the given and metaphysical realism see Raimo Tuomela, 'The Myth of the Given and Realism' (see footnote 12).

42 This is how Richard Schantz reformulates McDowell's position with regard to the problem of experience as merely being the cause of certain convictions. Cf. Richard Schantz, 'Wahrnehmung und Welt', in Wirklichkeit und Wahrnehmung des Heiligen, Schönen, Guten: Neue Beiträge zur Realismusdebatte, ed. by Elisabeth Heinrich and Dieter Schönecker (Paderborn: Mentis, 2011), pp. 17-37, esp. 32-34, referring to John McDowell, Mind and World (Cambridge: Cambridge University Press, 1994), pp. 14-18, 137-147.

${ }^{43}$ For further discussion on whether or not certain concepts of religious experience lead to anti-realism see Winfried Löffler, 'Die Rolle religiöser Erfahrung bei Swinburne, Plantinga und Alston', in Wirklichkeit und Wahrnehmung des Heiligen, Schönen und Guten (see footnote 42), pp. 67-123. 
cognitive powers. But, actually, he is in no position to show why - for instance - Christian expressions of religious experiences are not equally subject to suspicion as are the outcomes of other, non-Christian religious traditions. His concept remains unavoidably hypothetical, even ad-hoc at that point. ${ }^{44}$

If we do not focus on the rather rare occasions of a more or less direct encounter with the ultimate (as some claim for mystical experiences) but on patterns of a more common way to introduce religious experience to the epistemology of religious belief we cannot take away the necessity of interpretation: Why is it that the night sky or the impressive skyline of the Bavarian Alps inspire our sense of wonder and grandeur, and eventually lead to religious expressions? And why is it that some people might agree with our religious expression - based on the very same signs -whilst another might not? The case of religious expressions which are based on certain experiences cannot be compared to everyday sense perception even if an element of interpretation is still in place presumably at the most basic level of perception: Why is it that we all of a sudden interpret the appearance of a group of people as the appearance of the Simpson family, for instance, and not as the appearance of Homer, Marge and their kids? Why is it that we see something as a townhouse instead of a two story building? ${ }^{45}$ But maybe nothing depends on those differences in interpreting something as something based on the concepts we have that rest on the convictions we share. In the case of religious experience, however, differences become crucial; they might accumulate to the point of disagreement while the disagreement cannot be settled on the ground that one interpretation of an event is true while the other is not. Let us take, for example, a less ambitious and more common event - like the glowing of a mountain top during sunset. Based on the premise of faith and the concepts that come with it, a religious person is motivated and justified in interpreting this event as a sign of the creator's beauty given as gift to creation. But, equally, a non-religious person would be motivated

${ }^{44}$ For further discussions see Thomas Schärtl, Glaubens-Überzeugung. Philosophische Bemerkungen zur Erkenntnistheorie des christlichen Glaubens (Münster: Aschendorff, 2007), pp. 237-256.

${ }^{45}$ For the German philosopher Günter Abel, the fact that even the most basic forms of experience are immersed in interpretation makes interpretation itself basic and unavoidable - with interesting consequences for metaphysical realism; cf. Günter Abel, Interpretations-Welten: Gegenwartsphilosophie jenseits von Essentialismus und Relativismus (Frankfurt a.M.: Suhrkamp, 1995), pp. $448 f$. 
and even justified to see the glowing mountain just a spectacular event provided by the central star of our solar system. Religious experiences resemble experiences of beauty insofar as we are free to 'have' them free not just in a voluntary sense but also in the sense of being free from an epistemic duty to see something as something. But perhaps some are inclined to think that this account of religious experience, which always leaves the door open for legitimate engagement or disengagement in interpretation, is too liberal a way of conceiving of religious experiences. However, the outlined aspects of freedom of interpretation cohere with the doxastic freedom that belongs essentially to religious beliefs. Especially from a theistic point of view, which sees faith as the initial step the finite creature takes in order to engage into a partnership with the divine beneficiary, the freedom of faith must remain an irreplaceable requirement. But if it is equally legitimate to interpret an event as a religious experience and if it also legitimate to not interpret it that way, we are left with contradictions unless we embrace anti-realism again.

Not just religious experiences but also religious symbols are an integral part of a religious worldview. But religious qualities of events or things do not supervene on the physical properties of things and facts in a lawlike manner that can be logically pictured by a necessary implication. Pretty much everything can be filled with religious meaning while those who do not share certain concepts or do not add the premise of faith won't detect anything meaningful. ${ }^{46}$

It may be the case that events and things offer something like a basic meaning they are at least opened up for (and this idea is highly disputable, but - for the time being - we might concede the notion of a basic meaning to the realist). Whether or not this is the case becomes quite irrelevant once we consider that religious meaning is placed at a second-order-level of giving meaning to things at events. Of course, there still might be first-order-meaning in religious contexts, maybe the existence of God or some instances of direct encounter of God (although in Kant and Wittgenstein we will find the idea that it is rather illusory to interpret the existence of God as a case of first-order-meaning of things or events) can be exemptions. But the richness of a religious worldview is not built upon the rather sparse confession that a God exists and some people have encountered him. Rather the richness of a religious

${ }^{46}$ Cf. Joseph Runzo, World Views and Perceiving God (New York: St. Martin's Press, 1993), pp. 67-93, 115-141. 
worldview depends on the many instances in which we ascribe (secondorder-)meaning to things and events: Events can become the answer to a prayer because I see them like that while nothing in their mundane and physical layout dictates to treat them like an answer to my prayer. In a much larger scale the homecoming of Israel after the exile can be seen as an act of God although nothing in the physical and political layout of those events points to supernatural powers; in a non-religious worldview events like that can be traced back to rather mundane causes like the powers that be which somehow change their minds or select different political aims while setting those free that might have been under the burden of previous aims. Again, the premise of faith and the religious concepts we have guide our interpretation.

Perhaps not in every respect but for the most parts of religious worldviews we can say that they rest on acts of constructing a worldview. The term 'construction' has a very bad reputation because it insinuates that we make things up that have no basis 'in reality' or make an interpretation out of thin air. But we shouldn't be appalled by the phrase when something deeper is concerned: Interpretation is an act; it is simultaneously receptive and creative. Especially at the level of secondorder-meanings the creative aspect outweighs the receptive aspect, although both aspects cannot be separated. Thus, we add interpretation to something, although this addition cannot be 'clinically' separated from what we try to interpret. The interpretation is like the light we need to see that Gestalt ${ }^{47}$ of facts - a Gestalt we attribute to the facts based on how we actively see the facts. The Gestalt that emerges is nothing that is not permitted by the facts or things we focus on; it has to be in accordance with them. But, nevertheless, the Gestalt is an entity that gets its life from the relation we establish to things and facts by interpretation. In underlining the active side of interpretation and the mind-dependency of Gestalt we might as well call interpretation an act or a construction. Of course, in drawing a parallel between interpretation and construction we must not think that interpretation is up for a pure decision or

${ }^{47}$ I am using the phrase 'Gestalt' in a way Hans Urs von Balthasar has introduced this phrase to theological discourse. Cf. Hans Urs von Balthasar, Herrlichkeit, Vol. 1: Schau der Gestalt (Einsiedeln: Johannes Verlag, 1988). In short, it should be treated as an abbreviation to underline the fact that in seeing something we see something as something. In using this phrase I want to allude to the fact that there are only degrees that turn the case that two persons see something differently into the case when two persons see something different. 
depends on a consensus or is open to the powers of the highest bidder. That is not how interpretation works. Nevertheless, interpretations are parts of what Wittgenstein would have called forms of life - patterns of communication we share with each other (even at a subconscious, prerational level). If engaging in communication and if using the patterns of communication that we have established in our forms of life can be seen as acting, we may be justified in underlining the pro-active, constructive side of communication.

\section{SEARCHING FOR A BROADER PERSPECTIVE}

Maybe the above sketched remarks on antirealism are still premature. And maybe those positions are more accurate which think that the controversy as such indicates a premature framework of thinking, so that - at the end - the solution of the debate is the dissolution of the premises that lead to the controversy in question.

From this angle, it makes sense to regard Wittgenstein's view as a subtle paradigm that criticizes the very presuppositions of this debate and which tries to resolve the problems attached to the controversy in question from 'within' 48 (i.e. from within the execution of knowledge and the performances that language enables us to do). Seeing Wittgenstein as a role-model for overcoming the presuppositions of the controversy as such makes his view comparable even to Hegel who, in a speculative thread of mastery, tried to resolve the realism/antirealism-controversy from above as well as from below. Although it is not possible to chart all the consequences this approach has for the philosophy of religion, the Wittgenstein-Hegel alliance might serve as a silent warning or as a very strong reminder that the much invoked criterion of mind-independence is not in itself easy to grasp, let alone to describe and might eventually turn out to be devoid of meaning.

For in Wittgenstein as in Hegel we find an interpretation of minddependence that makes semantics and thinking the cement of the

${ }^{48}$ For a non-Wittgensteinian undermining of the realism/antirealism controversy compare Werner Stegmeier, 'Diesseits von Realismus und Anti-Realismus: Die Realität der Orientierung, in Wirklichkeit und Wahrnehmung des Heiligen (see footnote 42), pp. 39-63. Werner Stegmeier's approach is predominantly hermeneutical and semiotic. What is very interesting about his solution is the positive role played by reasoning and justification which actually shows that one can steer away from metaphysical realism without giving up the ideals of objectivity and cognitivity. 
universe - in a way that would render any concept of mind-independent reality truly useless and, even more so, meaningless. ${ }^{49}$ Their argument for attacking the realist's concept of mind-independence would come down to the following (admittedly somewhat oversimplified) conclusion:

(1) If any answer to any question of existence depends crucially on our approach to what we think reality to be (like), there is no answer to questions of existence independent of the mind. [Premise]

(2) Anything we think reality to be (like) depends crucially on our approach to reality. [Premise]

(3) There is no meaningful answer to questions of existence independent of the mind. [From $1 \& 2, \mathrm{MP}$ ]

Of course the crucial premise is sentence 2). It would take another paper to get into the details of how Wittgenstein and Hegel might really justify this courageous premise. Some hints might suffice: Wittgenstein would point out that existence-statements (as any statements) are certain types of predication - which are, by the way, always in danger of being messed up with regular predications - and that predicating is by itself a type of language game that is governed by the structures of our language. However, it would be misconceived, according to Wittgenstein, to call this 'interpretation' since what we do in language is not just an addition to whatever we get in perceiving reality but is the way how perceiving works at any rate. These structures, Wittgenstein would add, are determined predominantly, if not exclusively, by our actions and the patterns of our communicative behaviour and not by certain facts reality might consist of - independently of our approach to reality and independently of our actions and behaviour. ${ }^{50}$ Nevertheless, these structures are not something that is thrown on reality like a net we use to capture the fish of experience (this might be a rather Kantian notion of epistemology) but emerge, so to speak, out of reality itself, since our actions and patterns of communication are integral parts of reality and cannot be separated antiseptically from what counts as objective reality 'as such'. For, if we

49 I am grateful to Florian Rieger for a number of substantial discussions on Wittgenstein and Hegel. The point of comparison can be found in the major topics discussed in the Philosophical Investigations on the one hand and in the Wissenschaft der Logik on the other.

${ }^{50}$ Cf. Gordon P. Baker and Peter M. S. Hacker, Wittgenstein: Rules, Grammar and Necessity: An Analytic Commentary on the Philosophical Investigations, Vol. 2 (Oxford: Blackwell, 1988). 
look for the pure 'as such' of reality apart from what our language does for addressing reality, we will end up empty-handed.

Hegel's view, in contrast, is rather multi-layered. But in his Phenomenology of the Spirit we find quite a number of initial hints that support premise 2) while turning the mind-independency-thesis from heads to tails: Hegel emphasizes, for instance, that no entity has an identity and thus can be approached as the individual instantiation of a universal without a necessary relation to consciousness and selfconsciousness. The way Hegel discusses these issues suggests that in a world without consciousness a significant account of identity and thisness would be impossible, since identity crucially depends on a mind's capacity to identify something as something and since thisness depends on a consciousness's ability to refer to something as something. ${ }^{51}$ But this is just one side of the story: It is as well the activity of the mind executed as consciousness and self-consciousness that provides entities with individuality, identity and thisness as it is the entity's own substantiality which grants individuality and thisness. To say so is, indeed, applied dialectics which has the goal to overcome the unhealthy separation of reality and consciousness. Since the mind-dependency-thesis as well as the independency-thesis presuppose a dyadic relation between the mind and the world, it is Hegel's aim to undermine this very relation in emphasizing that there are no such hemispheres that could be separated antiseptically in ways that make the dyadic relation work. Therefore, whatever makes an entity an individual or a substance is exactly what echoes within consciousness as the conceptually graspable essence of this very entity.

A consequence of both views might be to either abandon truthmaker talk (in a deflationist way) or to open truthmaker talk up to the idea that not only states of affairs but also substances, relations, properties and universals, and concepts can serve as truthmakers and can, therefore, constitute facts (seen as obtaining states of affairs in the broadest sense).

${ }^{51}$ Cf. for instance Georg W. F. Hegel, Phänomenologie des Geistes (Hamburg: Meiner, 1988), p. 89: 'Es fällt hiermit das letzte Insofern hinweg, welches das für sich Sein und das Sein für anderes trennte; der Gegenstand ist vielmehr in einer und derselben Rücksicht das Gegenteil seiner selbst; für sich, insofern er für anderes, und für anderes, insofern er für sich ist. Er ist für sich, in sich reflektiert, Eins; aber dies für sich, in sich reflektiert, Ein Sein ist mit seinem Gegenteile, dem Sein für ein anderes, in einer Einheit, und darum nur als Aufgehobenes gesetzt; oder dies für sich Sein ist eben so unwesentlich, als dasjenige, was allein das Unwesentliche sein sollte, nämlich das Verhältnis zu anderem.' 
Therefore, any notion of reference that is more or less bound to the model of naming spatiotemporal things leads us astray once we raise truthmaker questions enclosed in questions of reference. Moreover, at least for Hegel, truth is a matter of revealing the conceptual side of states of affairs - which could be translated into the idea that states of affairs can serve as truthmakers only once they are seen as instantiations of universals that already serve as a bridge between the mind and the world. In a more sober way Wittgenstein would add that referring is not just one language game among others but a family of games resembling each other. Thus, what counts as a fact depends crucially on the fact-game we are immersed in and the rules we apply. Therefore, the truthmakerquestion has to be rephrased into the question of whether the rules that govern our language game are meant to present something as a fact or as a given entity.

To this very brief sketch of Hegel's and Wittgenstein's most fundamental intuitions regarding the realism/antirealism problem, we could as well add a short corollary introducing a more Putnam-like style of reasoning (which is, as it stands, not yet a deductive argument):

(1) If we meaningfully ascribe 'existence' to something, this ascription has to be reformulated in a way that reveals how we epistemically and semantically approach existence.

(2) If we reflect on the ways in which we epistemically or semantically approach existence, we need to treat this as a version of the question of whether or not our concepts are empty.

(3) Concepts are mind-dependent.

It is not the goal of this paper to discuss the above-mentioned line of reasoning; we just should keep it in mind as a kind of warning telling us that the foundations of the realism/antirealism controversy are so tied to the most basic issues in philosophy that it might be appropriate to constantly question the meaning of the key terms involved.

As already noted, it is not so clear what this does for the philosophy of religion. For Hegel we can state that he takes the notion of God as a regulative idea of reasoning and puts it at the very centre of what is meant to be an objective reality which is, nevertheless, mind-dependent insofar as this idea reflects the absolute spirit which encapsulates every mind-gifted existence as such. What religion is dealing with becomes itself part of the self-reflection of this very spirit, and is therefore an objective reality but, of course, not in a mind-independent way. But, actually, 
this is not a problem for Hegel since the mind-independency thesis, as pointed out, has lost its grip on us and on the criteria that determine reality. Wittgenstein, on the other hand, could be seen as someone who voluntarily and subtly brackets the idea of an absolute spirit in order to make us aware of the sheer contingency of everything underneath this very idea. And thus, the point of philosophy may turn into a 'religious point of view' (to use Norman Malcolm's ${ }^{52}$ famous words) because it makes us aware that no God's eye point of view exists underneath the idea of an absolute spirit - telling us that the realist's desperation, which emerges from aiming at this God's eye point of view without ever getting hold of it, is truly a religious attitude if taken as a reflection of the mark that contingency has put on us.

Acknowledgment. This paper was originally presented in Mainz, Germany, at a conference for the Analytic Theology Project, generously funded by the John Templeton Foundation.

${ }^{52}$ Cf. Norman Malcolm, Wittgenstein: A Religious Point of View (Ithaca: Cornell University Press, 1994). 